\title{
Correction to: The role of microRNA-133b and its target gene FSCN1 in gastric cancer
}

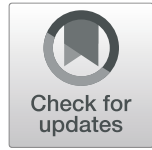

Lihua Guo ${ }^{1,2+}$, Hua Bai ${ }^{3+}$, Dongling Zou ${ }^{4+}$, Tao Hong $^{2}$, Jie Liu', Jiaqiang Huang ${ }^{2}$, Pengfei He ${ }^{5}$, Qi Zhou ${ }^{4^{*}}$ and Jinsheng $\mathrm{He}^{2^{*}}$

\section{Correction to: J Exp Clin Cancer Res 33, 99 (2014) https://doi.org/10.1186/s13046-014-0099-0}

Following publication of the article [1], the authors identified errors in Figs. 3, 4 and 6; specifically panels Fig. 3c (HGC-27 'untreated'), Fig. 4c (GES 'untreated'), Fig. $6 \mathrm{c}$ and $\mathrm{d}$. The corrections do not change the results or the conclusions of this paper.

\section{Author details \\ ${ }^{1}$ School of Computer and Information Technology, Shangyuan Residence, Haidian District, Beijing 100044, China. ${ }^{2}$ College of Life Sciences and Bioengineering, Beijing Jiaotong University, Shangyuan Residence, Haidian District, Beijing 100044, China. ${ }^{3}$ Department of Ophthalmology, General Hospital of Bei Jing Command of PLA, \#5 Nanmencang, DongCheng District, Beijing 100700, China. ${ }^{4}$ Department of Gynecologic Oncology, Chongqing Cancer Institute, Chongqing 400030, China. ${ }^{5}$ National Institutes for Food and Drug Control, No.2 Tiantan Xi Li, Beijing 100050, China.}

Published online: 20 October 2020

\section{Reference}

1. Guo L, Bai H, Zou D, et al. The role of microRNA-133b and its target gene FSCN1 in gastric cancer. J Exp Clin Cancer Res. 2014;33:99. https://doi.org/ 10.1186/s13046-014-0099-0.

\footnotetext{
The original article can be found online at https://doi.org/10.1186/s13046014-0099-0.

*Correspondence: qizhou9128@163.com; jshhe@bjtu.edu.cn

${ }^{+}$Lihua Guo, Hua Bai and Dongling Zou contributed equally to this work.

${ }^{4}$ Department of Gynecologic Oncology, Chongqing Cancer Institute, Chongqing 400030, China

${ }^{2}$ College of Life Sciences and Bioengineering, Beijing Jiaotong University, Shangyuan Residence, Haidian District, Beijing 100044, China

Full list of author information is available at the end of the article
}

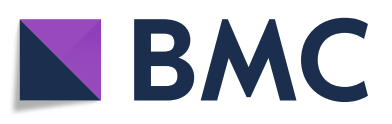

( ) The Author(s). 2020 Open Access This article is licensed under a Creative Commons Attribution 4.0 International License, which permits use, sharing, adaptation, distribution and reproduction in any medium or format, as long as you give appropriate credit to the original author(s) and the source, provide a link to the Creative Commons licence, and indicate if changes were made. The images or other third party material in this article are included in the article's Creative Commons licence, unless indicated otherwise in a credit line to the material. If material is not included in the article's Creative Commons licence and your intended use is not permitted by statutory regulation or exceeds the permitted use, you will need to obtain permission directly from the copyright holder. To view a copy of this licence, visit http://creativecommons.org/licenses/by/4.0/. The Creative Commons Public Domain Dedication waiver (http://creativecommons.org/publicdomain/zero/1.0/) applies to the data made available in this article, unless otherwise stated in a credit line to the data. 

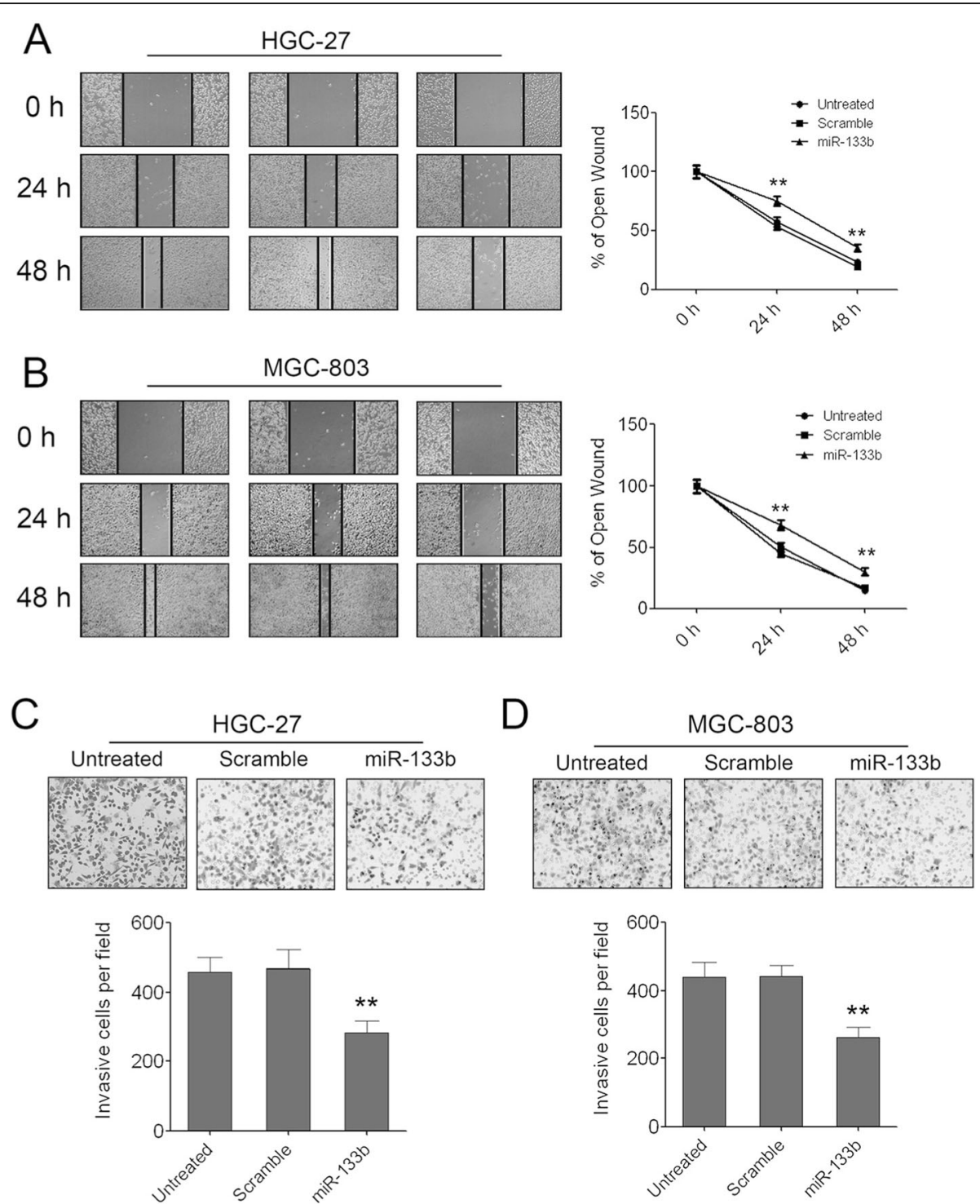

Fig. 3 Enforced expression of miR-133b can inhibit GC cell migration and invasion. (A) The pictures of wound healing and the percentages of open wound of HGC-27 cells at 0, 24, 48 hours after scratching. Data are shown as mean + s.d. $(n=3) ;{ }^{* *}$ indicates P-value $<0.01$. (B) The pictures of wound healing and the percentages of open wound of MGC-803 cells at 0, 24, 48 hours after scratching. Data are shown as mean + s.d. $(n=3)$; ${ }^{*}$ indicates P-value $<0.01$. (C) The invaded HGC-27 cells in the Matrigel transwell invasion assay. Data are shown as mean $+s . d$. $(n=3)$; ** indicates P-value <0.01. (D) The invaded MGC-803 cells in the Matrigel transwell invasion assay. Data are shown as mean $+s . d$. $(n=3)$; ** indicates P-value $<0.01$ 

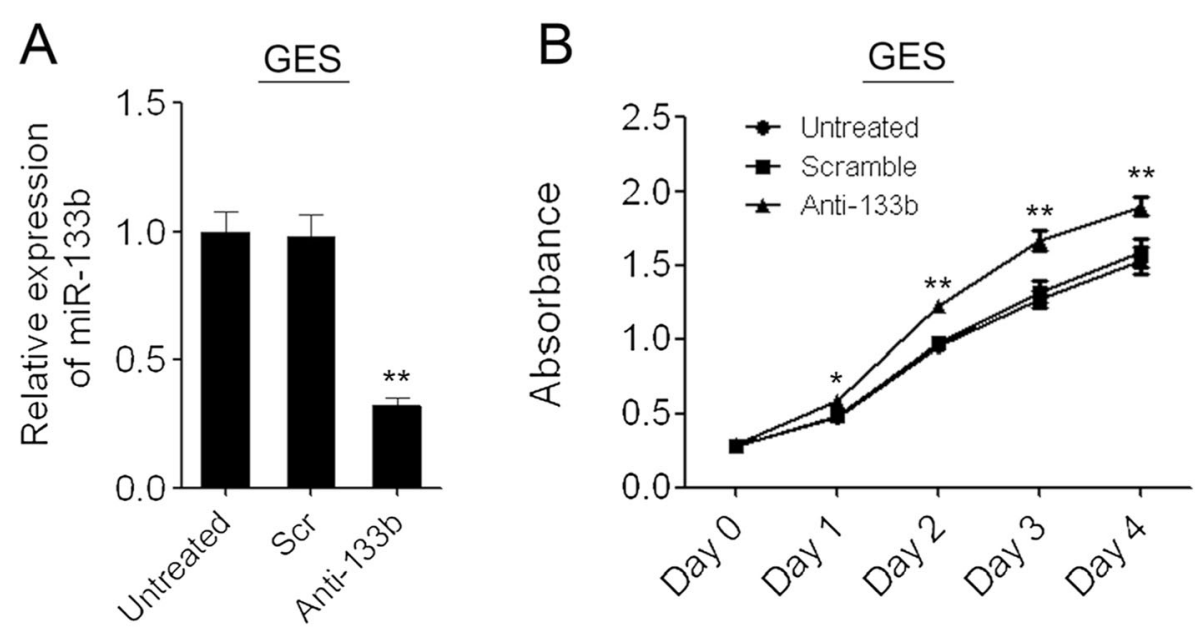

C

GES
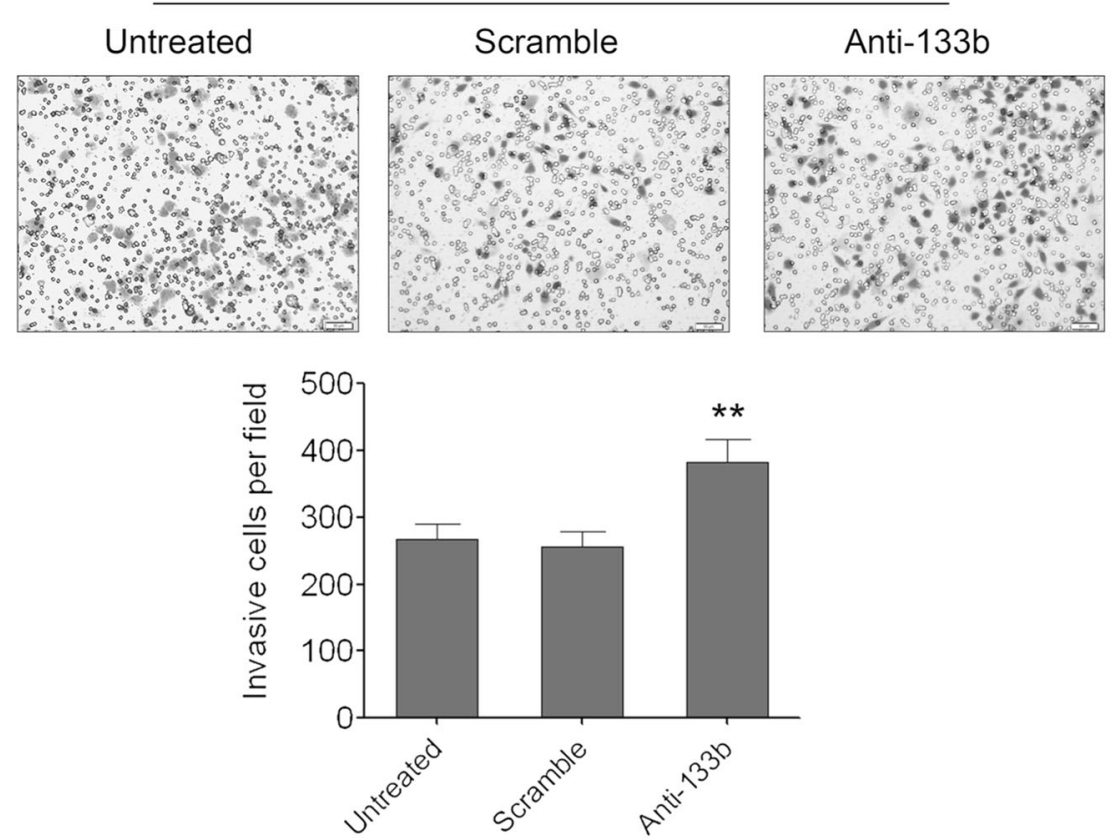

Fig. 4 Knockdown of miR-133b in GES cells can promote cell proliferation and migration. (A) Inhibition of miR-133b in GES cells was confirmed by qRT-PCR. (B) The cell growth of GES cells at day 0, 1, 2, 3, 4 post transfection which was detected by CCK-8 assay. Data are shown as mean \pm s.d. $(n=3) ;{ }^{*}$ indicates P-value $<0.05 ; * *$ indicates P-value $<0.01$. (C) The invaded GES cells in the Matrigel transwell invasion assay. Data are shown as mean + s.d. $(n=3) ;{ }^{* *}$ indicates P-value $<0.01$ 


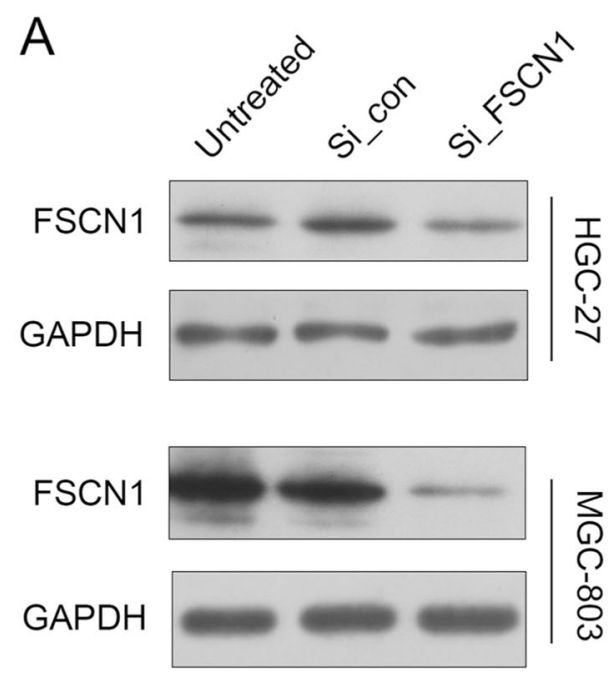

B

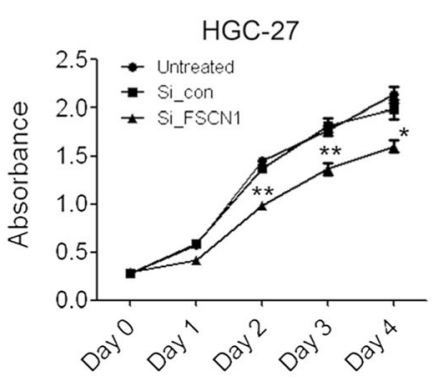

MGC-803

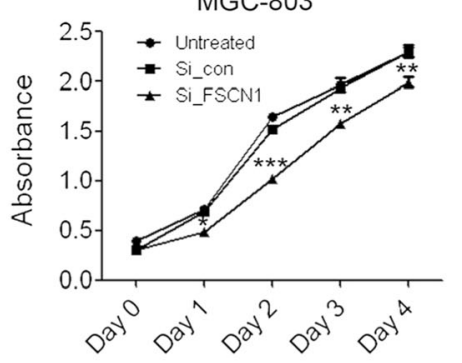

C

HGC-27

$\mathrm{D}$
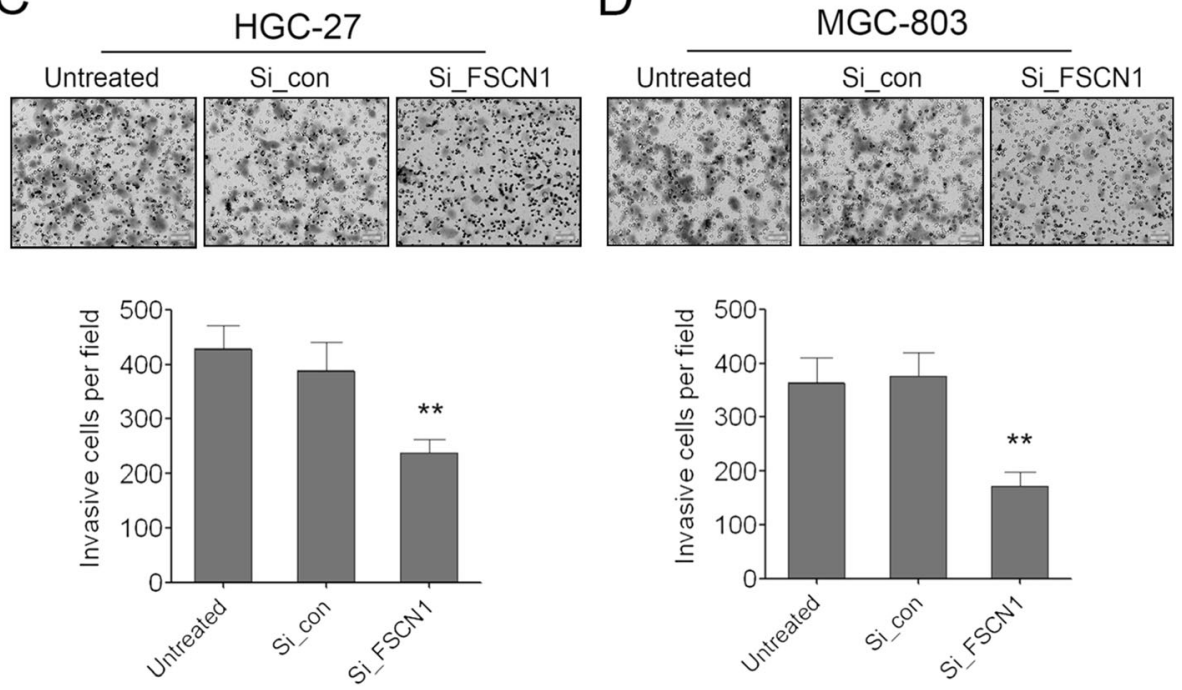

$E$
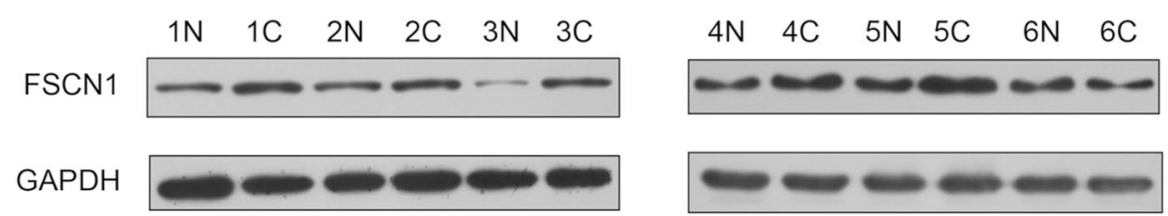

Fig. 6 Knock down of FSCN1 can inhibit GC cell growth and invasion. (A) Western blot analysis of FSCN1 expression in HGC-27 and MGC803 cells transfected with negative control or FSCN1 siRNAs. (B) The cell growth of HGC-27 and MGC-803 cells at day 0, 1, 2, 3, 4 post transfection which was detected by CCK-8 assay. Data are shown as mean + s.d. $(n=3)$; ${ }^{*}$ indicates P-value $<0.05$. ${ }^{* *}$ indicates $P$-value $<0.01$. ${ }^{* * *}$ indicates P-value $<0.001$. (C) The invaded HGC-27 cells in the Matrigel transwell invasion assay. Data are shown as mean $+s . d$. $(n=3)$; ${ }^{* *}$ indicates P-value <0.01. (D) The invaded MGC-803 cells in the Matrigel transwell invasion assay. Data are shown as mean $+s . d$. $(n=3)$; ${ }^{* *}$ indicates $P$-value $<0.01$. (E) Western blot analysis of FSCN1 expression in 6 pairs of GC tissues (C) and the adjacent non-neoplastic tissues (N) 